JURNAL PENDIDIKAN USIA DINI

DOI: https://doi.org/10.21009/JPUD.122
DOI: https://doi.org/10.21009/JPUD.122.17

\title{
PENGEMBANGAN MODEL PENILAIAN PENDIDIKAN KARAKTER ANAK USIA DINI
}

\author{
Veny Iswantiningtyas ${ }^{1}$, Widi Wulansari ${ }^{2}$ \\ Universitas Nusantara PGRI Kediri \\ E-mail: veny@unpkediri.ac.id ${ }^{1}$, widiwulansari@unpkediri.ac.id ${ }^{2}$
}

\begin{abstract}
ABSTRAK
This research aims to develop an early childhood character education assessment model. The research method used is the $R \& D$ model developed by Borg \& Gall. The implementation of this model development was carried out in 6 stages, namely information gathering, planning, model development, initial product testing, product revision, and main field test. The instrument had developed by the procedure and criteria for item validity and instrument reliability. The first phase of the trial was conducted in Taman Indria Kindergarten, Pare District. The second phase of the trial was conducted at Tauladan Kindergarten and Dharma Wanita Pelem Kindergarten in Pare District. Data from the trial and main field tests were analyzed using factor analysis. The results of this study are as follows: 1) there are 18 character values with 65 indicators indicating that all indicators contribute effectively to the factors in each character value variable, 2) almost all indicators in each character value are strongly and significantly correlated with other indicators so that the assessment model that has been developed can assess all values of character education that have been taught for one semester, 3) according to the results of the questionnaire that has been analyzed it can be concluded that the use of early childhood character education assessment models is very effective to be applied in Kindergarten child.
\end{abstract}

Keywords: Assessment model Development, Character Education Assessment Model, Early Childhood

Penelitian ini bertujuan untuk mengembangkan model penilaian pendidikan karakter anak usia dini. Metode penelitian yang digunakan adalah model R\&D yang dikembangkan oleh Borg \& Gall. Pelaksanaan pengembangan model ini dilakukan dalam 6 tahapan, yaitupengumpulan informasi, perencanaan, pengembangan model, uji produk awal, revisi produk, dan uji lapangan utama.Instrumen yang digunakan telah memenuhi syarat sebagai instrumen yang valid dan reliabel.Uji coba tahap pertama dilakukan di TK Taman Indria Kecamatan Pare. Uji coba tahap kedua dilakukan di TK Tauladan dan TK Dharma Wanita Pelem Kecamatan Pare. Data hasil uji coba dan uji lapangan utama dianalisis menggunakan analisis faktor. Hasil penelitian ini adalah sebagai berikut: 1) terdapat 18 nilai karakter dengan 65 indikator yang menunjukkan bahwa seluruh indikator memberikan sumbangan yang efektif terhadap faktor dalam variabel tiap-tiap nilai karakter, 2) hampir semua indikator pada tiap-tiap nilai karakter berkorelasi kuat dan signifikan dengan indikator yang lain sehingga model penilaian yang telah dikembangkan dapat menilai seluruh nilai pendidikan karakter yang telah diajarkan selama satu semester,3) sesuai hasil angket yang telah dianalisis dapat disimpulkan bahwa penggunaan model penilaian pendidikan karakter anak usia dini sangat efektif untuk diterapkan di Taman Kanak-kanak.

Kata Kunci :Pengembangan model penilaian, Model Penilaian Pendidikan Karakter, Anak Usia Dini. 


\section{PENDAHULUAN}

Pembentukan karakter atau akhlak mulia dalam membangun sebuah masyarakat yang tertib, aman, dan sejahtera menjadi pondasi penting bagi terbentuknya sebuah tatanan masyarakat yang beradab dan sejahtera. Oleh karena itu, kesadaran akan pembentukan karakter harus dimulai sejak anak usia dini (Dirjen PAUD, 2012). Pendidikan karakter perlu ditanamkan dan dikenalkan pada anak sejak dini agar mereka mempunyai pondasi yang kuat untuk menghadapi tantangan di masa depannya. Tujuan pendidikan nasional sebagaimana tersebut dalam Pedoman Pendidikan Karakter Pada Anak Usia Dini merupakan rumusan kualitas yang harus dicapai oleh setiap warga negara Indonesia, dengan pengembangan Pendidikan Karakter yang tidak lepas dari nilai-nilai dasar yang dipandang baik.

Ahli pendidikan moral Lickona (1992) menyebutkan, setidaknya ada 6 karakter, yaitu: jujur, kasih sayang, keberanian, baik, kontrol diri, tekun. Dimerman (2009) mengidentifikasi 10 karakter yang harus dikembangkan yaitu: respect, responsibility, honesty, empaty, fairness, initiative, courage, perseverance, optimism dan integrity.

Pendidikan karakter pada anak usia dini dapat dilakukan dengan bermain. Pendidikan karakter tidak berarti penyampaian pengetahuan tentang karakter yang baik, namun juga pembiasaan dalam kehidupan sehari-hari yang teraplikasi dalam kegiatan bermain. Terdapat 5 karakter yang dapat dibangun pada anak usia dini melalui permainan keretakeretaan, balok, bermain peran dan bercerita (Khoiriyah, 2016). Sedangkan menurut Chasanah (2014) percobaan sains sederhana dapat digunakan sebagai metode penanaman nilai-nilai karakter pada anak usia dini. Penilaian dilakukan untuk menjamin bahwa pendidikan karakter telah berhasil ditanamkan oleh pendidik/guru. Penilaian merupakan komponen keenam dalam kompetensi pedagogik yang harus dipahami oleh guru. Di dalam kompetensi tersebut, guru perlu memahami bagaimana menyelenggarakan dan membuat laporan penilaian, menentukan fokus sasaran penilaian proses dan hasil pembelajaran pada anak usia dini serta menggunakan hasil penilaian, pengembangan dan evaluasi program untuk kepentingan perkembangan anak (Chasanah, 2014).

Direktorat Pembinaaan

Pendidikan Anak Usia Dini (2012) telah menerbitkan pedoman penilaian nilai-nilai karakter di Lembaga PAUD yaitu: Belum Muncul/BM artinya Belum menunjukkan perilaku yang diharapkan, Mulai Muncul/MM artinya anak mulai menunjukkan perilaku yang diharapkan dengan bantuan orang lain, Sering Muncul/M artinya anak menunjukkan perilaku yang dihararapkan namun terkadang masih perlu diingatkan, Konsisten/K artinya sudah menjadi kebiasaan anak 
Pengembangan Model Penilaian.

Veny \& Widi

secara otomatis dan tidak perlu diingatkan. Hasil penelitian yang dilakukan Rohita\&Nurfadilah (2017) menunjukkan bahwa adanya kekurang sesuaian antara penilaian yang dilakukan oleh guru berdasarkan prinsip penilaian. Sebagai contoh, untuk menentukan keberhasilan pendidikan karakter melalui percobaan sains sederhana menggunakan kriteria penilaian Ya dan Tidak (Chasanah, 2014). Hasil observasi dan wawancara di lapangan juga menunjukkan bahwa belum adanya penilaian pendidikan karakter secara khusus. Selama ini penilaian pendidikan karakter masih menjadi satu di dalam penilaian keenam aspek perkembangan anak. Berdasarkan beberapa pendapat diatas diperlukan suatu model pengembangan penilaian pendidikan karakter dalam pembelajaran di PAUD sesuai dengan karakteristik anak usia dini. Dengan dikembangkannya model penilaian penidikan karakter dalam pembelajaran di PAUD akan mempermudah guru-guru PAUD dalam melakukan penilaian, sehingga implementasi pendidikan karakter bagi anak usia dini dapat terlaksana guna mendukung tujuan pendidikan nasional.

Penilaian hasil kegiatan belajar di PAUD merupakan sebuah proses menggumpulkan dan menelaah informasi secara sistematis, terukur, berkelanjutan, serta menyeluruh tentang pertumbuhan dan perkembangan yang telah dicapai oleh anak selama kurun waktu tertentu (Lestariningrum, 2016). Oleh karena itu, guru harus mampu menggunakan metode, teknik dan instrumen yang tepat dalam melakukan penilaian agar hasil penilaiannya akurat. Melalui penilaian, guru akan dapat mengetahui keberfungsian proses pembelajaran, terutama yang berkaitan dengan materi, metode dan perilaku anak selama proses pembelajaran berlangsung.

Berdasarkan permasalahan yang telah dikemukakanmaka akan dilakukan penelitian untuk mengetahui "Bagaimana pengembangan model penilaian pendidikan karakter anak usia dini?" Adapun tujuan dari penelitian ini adalah: (1) Mengembangkan model penilaian pendidikan karakter anak usia dini yang dapat membantu guru dalam mengidentifikasi nilai-nilai karakter mana yang sudah berhasil tertanam pada anak dan mana yang belum. (2) Menelaah efektivitas pengembangan model penilaian pendidikan karakter anak usia dini.

\section{KAJIAN TEORITIK}

\section{Pendidikan Karakter}

Karakter dapat dimaknai sebagai nilai, sikap, dan perilaku yang dapat diterima oleh masyarakat. Karakter meliputi berbagai hal seperti etis, demokratis, hormat, bertanggung jawab, dapat dipercaya, adil dan tidak curang, serta peduli (Suyanto, 2012). 
Dengan demikian, diperlukan pendidikan untuk membentuk karakter yang positif pada anak. Menurut Gunawan (2012) pendidikan karakter adalah upaya yang dirancang dan implementasikan secara sistematik untuk menanamkan nilai-nilai perilaku anak didik yang berhubungan dengan Tuhan, diri sendiri, sesama manusia, lingkungan yang terwujud dalam pikiran, sikap, perasaan, perkataan, dan perbuatan berdasarkan normanorma agama, hukum, tatakrama, budaya dan adat istiadat.

Lebih lanjut Lickona (2013) menjelaskan terdapat 3 komponen karakter yang baik yaitu: pengetahuantentang moral, perasaan tentang moral dan perbuatan bermoral. Hasil dari penelitian yang dilakukan oleh Park and Peterson (2004) bahwa pendidikan karakter yang baik adalah pendidikan yang dimulai dari lingkungan keluarga, dalam pendidikan karakter tersebut mampu membentuk anak yang memiliki sifat positif dalam berpikir, berempati dan berperilaku. Berdasarkan uraian tersebut dapat disimpulkan bahwa pendidikan karakter anak usia dini adalah pendidikan yang menanamkan nilai-nilai karakter luhur kepada anak didik norma-norma agama, hukum, tatakrama, budaya dan adat istiadat.

\section{Nilai-nilai Pendidikan Karakter} Anak Usia Dini

Nilai-nilai yang penting dikenalkan dan diinternalisasikan ke dalam perilaku mereka mencakup: Kecintaan terhadap Tuhan YME,
Kejujuran, Disiplin, Toleransi dan Cinta Damai,Percaya Diri, Mandiri, Tolong menolong, Hormat dan sopan santun, Tanggungjawab, Kerjakeras, Kepemimpinan dan keadilan, Kreatif, Rendah hati, Peduli Lingkungan, Cinta Bangsa dan Tanah Air (Direktorat Pembinaaan Pendidikan Anak Usia Dini, 2012). Megawangi (dalam Komalasari dan Saripudin, 2017) menegaskan bahwa nilai karakter yang selayaknya diajarkan kepada anak-anak meliputi : Cinta Tuhan dan segenap ciptaan-Nya, Kemandirian dan Tanggung Jawa, Kejujuran/ amanah, kebijaksaan, Hormat dan Santun, Dermawan, suka menolong dan gotong royong, Percaya diri, kreatif dan pekerja keras, Kepemimpinan dan keadilan, Baik hati dan rendah hati, Toleransi, kedamaian dan kesatuan.

\section{Penilaian Pendidikan Karakter Anak Usia Dini}

Pada umumnya, penilaian adalah suatu prosedur sistematis yang mencakup kegiatan mengumpulkan, menganalisis, dan menginterpretasikan informasi yang dapat digunakan untuk membuat kesimpulan tentang karakteristik objek yang diukur. Penilaian mencakup semua cara yang digunakan untuk menilai kinerja individu (Kusaeri dan Suprananto, 2012).

Sementara menurut Runtukahu dan Kandou (2014) penilaian merupakan suatu pernyataan berdasarkan sejumlah fakta karakteristik anak dan mencakup 
Pengembangan Model Penilaian.

Veny \& Widi

semua proses pembelajaran. Penilaian kinerja anak dilakukan untuk mengamati dan mengukur tingkat kemampuan anak dalam menyelesaikan suatu pekerjaan (Zulkifli, Majid dan Hassan, 2016).

Namun, penilaian pada anak usia dini bukan bertujuan untuk mengukur prestasi dan mencapai keberhasilan sekolastik. Penilaian yang dilakukan bertujuan untuk melihat tingkat kemajuan perkembangan serta kemampuan yang telah dilakukan anak dalam berbagai tindakan, sikap, kinerja, dan tampilan (Yusuf, 2009). Dalam melakukan penilaian pendidikan karakter terdapat beberapa prinsip yang harus diperhatikan guru/ pendidik yaitu: 1) Menyeluruh, 2) Berkesinambungan, 3) Objektif, 4) Mendidik, 5) Bermakna (Chasanah, 2014).

\section{Penilaian Pendidikan Karakter}

Penilaian adalah suatu proses untuk mengetahui keberhasilan suatu program kegiatan yang sesuai dengan tujuan atau kriteria yang telah ditetapkan (Sutijan, Makhfud, Lestari, \& Chumdari, 2015). Penilaian dapat berfungsi dengan baik jika tersedia data yang sesuai dengan tujuan penilaian tersebut. Menurut Mardapi (2012) penilaian adalah kegiatan untuk menentukan pencapaian hasil pembelajaran yang dikategorikan menjadi tiga ranah, yaitu ranah kognitif, psikomotor dan afektif. Hal ini didukung oleh pendapat Arndt dan Tesar (2015) yang menyatakan bahwa tujuan penilaian dapat dilihat sebagai sebuah metode umpan balik dalam proses pembelajaran, meningkatkan pengajaran, mengungkapkan pemahaman dan pemikiran ulang serta mengevaluasi kembali pembelajaran.Pendidikan karakter merupakan salah satu bidang dalam ranah afektif. Oleh sebab itu, penilaian pada pendidikan karakter merupakan suatu kegiatan yang dilakukan untuk mengukur kemampuan pada ranah afektif.

Penilaian pada pendidikan karakter merupakan penilaian yang memerlukan data baik kuantitatif maupun kualitatif. Menurut Andersen dalam Mardapi, (2012), terdapat dua metode yang dapat dilakukan untuk melakukan penilaian pada karakter seseorang, yaitu metode observasi dan metode laporan-diri. Metode observasi dilakukan untuk melihat perilaku atau perbuatan yang ditampilkan, sedangkan metode laporan diri digunakan untuk mengetahui keadaan dirinya sendiri.Data kualitatif diperoleh dari hasil pengamatan, sedangkan data kuantitatif diperoleh dari hasil pengukuran hasil pengamatan. Oleh karena itu, untuk dapat memperoleh data yang akurat tentang pendidikan karakter diperlukan instrumen yang berbentuk nontes, yaitu instrumen yang hasilnya tidak ada yang salah atau benar. 


\section{METODE PENELITIAN}

Penelitian yang dilakukan merupakan penelitian pengembangan atau sering disebut Research and Development $(R n D)$. Penelitian ini bertujuan untuk menemukan serta mengembangkan model penilaian pendidikan karakter untuk anak usia dini yang dapat dipergunakan sebagai alternatif penilaian di lembaga Pendidikan Anak Usia Dini. Tahap pelaksanaan prosedur pengembangan dalam penelitian ini menggunakan model Borg and Gall dengan penyederhanaan menjadi enam tahapan, yaitu Pada tahap pengumpulan informasi dilakukan kegiatan yang berupa identifikasi masalah dan mengumpulkan informasi.Kegiatan dalam tahap perencanaan adalah mendesain instrumen penilaian.

Tahapan berikutnya adalah tahap pengembangan model terdiri dari mengembangkan model dan indikator penilaian. Di dalam tahapan ini juga dilakukan validasi model yang dilakukan oleh 2 orang pakar di bidang pendidikan anak usia dini. Pada tahap uji lapangan awal dilakukan pada kelompok terbatas untuk mengetahui kelemahan dan kekurangan dari model penilaian yang dikembangkan.

Tahapan revisi produk dilakukan untuk memperbaiki kekurangan dari model yang dikembangkan. Tahapan yang terakhir adalah 6) uji lapangan utama. Kegiatan ini dilakukan untuk mengetahui keefektifan dari model penilaian pendidikan karakter yang dikembangkan. (Emzir, 2012).

\section{Tempat dan Waktu Penelitian}

Penelitian ini dilakukan di 3 (tiga) Taman Kanak-kanak yaitu Taman Kanak-kanak Tauladan, Taman Kanak-kanak Dharma Wanita Pelem dan Taman Kanak-kanak Taman Indria di Kecamatan Pare Kabupaten Kediri.

\section{Sampel Penelitian}

Penelitian ini menggunakan sampel Anak Usia Dini di Kecamatan Pare Kabupaten Kediri sebanyak 3 sekolah Taman Kanak-kanak. Sampel penelitian dipilih setelah peneliti melakukan studi pendahuluan ke beberapa TK yang ada di Kecamatan Pare. Pemilihan pengambilan sampel menggunakan purposive sampling, yaitu pemilihan sampel dengan pertimbangan: 1) subyek penelitian terlibat langsung dengan proses pembelajaran, 2) sampel yang dipilih dalam penelitian ini memiliki datadata sebagai sumber informasi sesuai yang dibutuhkan untuk penelitian. Ujilapangan awal model dilakukan di TK Taman Indria Pare, selanjutnya uji lapangan utama dilakukan di TK Tauladan dan TK Dharma Wanita Pelem.

\section{Teknik Pengumpulan dan Analisis Data}

Teknik pengumpulan data yang digunakan adalah angket. Teknik analisis dalam penelitian ini menggunakan statistik deskriptif. 
Pengembangan Model Penilaian.

Veny \& Widi

Instrumen dalam penelitian ini berupa skala penilaianpendidikan karakter dan angket. Instrumentersebut telah divalidasi oleh dua orang ahli (expert judgement) dalam bidang pendidikan anak usia dini. Hasil validasi instrumen dapat dilihat pada tabel berikut.

\section{Tabel 1. Hasil Validitas}

\begin{tabular}{c|c|c|c|c|c|c|c|c|}
\hline Item & $\begin{array}{c}\text { Koef } \\
\text { Valid }\end{array}$ & Ket. & Item & $\begin{array}{c}\text { Koef } \\
\text { Valid }\end{array}$ & Ket. & Item & $\begin{array}{c}\text { Koef } \\
\text { Valid }\end{array}$ & Ket. \\
\hline A1 & 0,541 & Valid & G1 & 0,586 & Valid & L3 & 0,677 & Valid \\
\hline A2 & 0,589 & Valid & G2 & 0,754 & Valid & M1 & 0,750 & Valid \\
\hline A3 & 0,612 & Valid & G3 & 0,754 & Valid & M2 & 0,568 & Valid \\
\hline A4 & 0,727 & Valid & G4 & 0,706 & Valid & M3 & 0,811 & Valid \\
\hline B1 & 0,704 & Valid & G5 & 0,571 & Valid & N1 & 0,811 & Valid \\
\hline B2 & 0,725 & Valid & G6 & 0,651 & Valid & N2 & 0,833 & Valid \\
\hline B3 & 0,695 & Valid & H1 & 0,669 & Valid & N3 & 0,720 & Valid \\
\hline C1 & 0,602 & Valid & H2 & 0,610 & Valid & O1 & 0,592 & Valid \\
\hline C2 & 0,644 & Valid & H3 & 0,696 & Valid & O2 & 0,718 & Valid \\
\hline C3 & 0,667 & Valid & I1 & 0,608 & Valid & O3 & 0,747 & Valid \\
\hline D1 & 0,674 & Valid & I2 & 0,732 & Valid & O4 & 0,819 & Valid \\
\hline D2 & 0,590 & Valid & I3 & 0,737 & Valid & P1 & 0,598 & Valid \\
\hline D3 & 0,613 & Valid & J1 & 0,745 & Valid & P2 & 0,598 & Valid \\
\hline E1 & 0,721 & Valid & J2 & 0,761 & Valid & P3 & 0,659 & Valid \\
\hline E2 & 0,679 & Valid & J3 & 0,764 & Valid & P4 & 0,693 & Valid \\
\hline E3 & 0,660 & Valid & K1 & 0,752 & Valid & Q1 & 0,799 & Valid \\
\hline E4 & 0,723 & Valid & K2 & 0,752 & Valid & Q2 & 0,735 & Valid \\
\hline F1 & 0,674 & Valid & K3 & 0,735 & Valid & Q3 & 0,811 & Valid \\
\hline F2 & 0,789 & Valid & K4 & 0,544 & Valid & R1 & 0,667 & Valid \\
\hline F3 & 0,686 & Valid & K5 & 0,699 & Valid & R2 & 0,648 & Valid \\
\hline F4 & 0,566 & Valid & L1 & 0,640 & Valid & R3 & 0,811 & Valid \\
\hline F5 & 0,623 & Valid & L2 & 0,708 & Valid & & & \\
\hline
\end{tabular}

Hasil validitas menunjukkan bahwa nilai untuk setiap item dari keseluruhan yang berjumlah 65 berada diantara 0,4-0,8 (Retnawati, 2016). Artinya, ke-65 item dari instrumen penilaian pendidikan karakter dapat dinyatakan valid. Hasil reliabilitas menunjukkan bahwa nilainya sebesar 0,983 . Berdasarkan ketentuan bahwa besarnya indeks keandalan yang dapat diterima adalah minimal 0,70 (Mardapi, 2012), maka ke-65 item dari instrumen penilaian pendidikan karakter dapat dinyatakan reliabel atau memiliki reliabilitas yang tinggi

\section{HASIL DAN PEMBAHASAN}

\section{Pengumpulan Informasi}

Pengumpulan informasi penelitian ini dilakukan dengan menggunakan metode wawancara pada guru dan kepala sekolah yang ada di Kecamatan Pare Kabupaten Kediri, untuk mengetahui bagaimana cara penilaian pendidikan karakter yang telah diterapkan. Lebih lanjut, peneliti juga melakukan observasi untuk mengamati proses belajar mengajar. Selain itu, peneliti juga mengumpulkan dokumen Program Semester, RPPM, dan RPPH tentang penanaman nilai pendidikan karakter.

\section{Perencanaan}

Berdasarkan hasil wawancara dan observasi yang telah dilakukan dapat diketahui bahwa belum ada penilaian khusus untuk pendidikan karakter. Oleh sebab itu, peneliti melakukan studi literasi untuk mengembangkan model penilaian pendidikan karakter berdasarkan pedoman Dirjen PAUD.

\section{Pengembangan Model}

Pada tahap ini, terdapat tiga kegiatan yang telah dilakukan. Tahap pertama, peneliti melakukan FGD (Focus Group Disscussion) untuk merancang draft penilaian pendidikan karakter. $F G D$ dilakukan bersama dengan 11 guru, 3 kepala sekolah, 2 ahli di bidang PAUD, dan 2 peneliti. Tahap kedua, dilaksanakan $F G D$ lagi untuk 
menyusun aspek-aspek yang dinilai dalam pendidikan karakter. Tahap ketiga, dilakukan lagi $F G D$ untuk menyusun indikator-indikator sesuai dengan aspek dalam pendidikan karakter. Hasil dari $F G D$ dirumuskan 18 nilai pendidikan karakter dengan 65 indikator dengan kriteria penilaian: BM (Belum Muncul), MM (Mulai Muncul), M (Muncul), dan SM (Sudah Muncul).

\section{Hasil Uji Lapangan Awal}

Hasil uji lapangan awal pengembangan model penilaian pendidikan karakter anak usia dini di TK Taman Indria Kecamatan Pare disajikan pada tabel 2.

Tabel 2. Hasil Uji Lapangan Awal

\begin{tabular}{|c|c|c|c|c|c|}
\hline Var. & Ind. & $\begin{array}{l}\text { Nilai } \\
\text { KMO } \\
\end{array}$ & $\begin{array}{l}\text { Sumb. } \\
\text { Efektif }\end{array}$ & $\begin{array}{c}\text { Koef. } \\
\text { Korelasi }\end{array}$ & Ket. \\
\hline \multirow{4}{*}{ 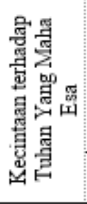 } & A1 & \multirow{4}{*}{0,654} & 0,783 & 0,647 & Sig. \\
\hline & $\mathrm{A} 2$ & & 0,715 & 0,603 & $\begin{array}{c}\text { Sig. } \\
\text { Tidak Sig. (A4) }\end{array}$ \\
\hline & $\mathrm{A} 3$ & & 0,679 & 0,766 & Sig. \\
\hline & A4 & & 0,386 & 0,609 & $\begin{array}{c}\text { Sig. } \\
\text { Tidak Sig. (A2) }\end{array}$ \\
\hline \multirow{3}{*}{ 萢 } & B1 & \multirow{3}{*}{0,579} & 0,767 & 0,552 & Sig. \\
\hline & B2 & & 0,614 & 0,579 & $\begin{array}{c}\text { Sig. } \\
\text { Tidak Sig. (B3) }\end{array}$ \\
\hline & B3 & & 0,462 & 0,645 & $\begin{array}{l}\text { Sig. } \\
\text { Tidak Sig. (B2) } \\
\end{array}$ \\
\hline \multirow{3}{*}{$\begin{array}{l}\text { 嗬 } \\
\text { 岁 } \\
\text { 总 }\end{array}$} & $\mathrm{C} 1$ & \multirow{3}{*}{0,556} & 0,291 & 0,871 & $\begin{array}{c}\text { Sig. } \\
\text { Tidak Sig. (C3) }\end{array}$ \\
\hline & $\mathrm{C} 2$ & & 0,861 & 0,533 & Sig. \\
\hline & $\mathrm{C} 3$ & & 0,841 & 0,535 & $\begin{array}{c}\text { Sig. } \\
\text { Tidak Sig. (C1) }\end{array}$ \\
\hline \multirow{3}{*}{$\begin{array}{l}\text { 慁 } \\
\text { 离 }\end{array}$} & D1 & \multirow{3}{*}{0,627} & 0,486 & 0,773 & Sig. \\
\hline & $\mathrm{D} 2$ & & 0,759 & 0,590 & Sig. \\
\hline & D3 & & 0,708 & 0,605 & Sig. \\
\hline \multirow{4}{*}{ 営嵒 } & E1 & \multirow{4}{*}{0,823} & 0,791 & 0,806 & Sig.... \\
\hline & E2 & & 0,848 & 0,761 & Sig. \\
\hline & E3 & & 0,755 & 0,860 & Sig. \\
\hline & E4 & & 0,615 & 0,912 & Sig. \\
\hline \multirow{5}{*}{ 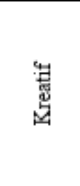 } & F1 & \multirow{5}{*}{0,777} & 0,667 & 0,751 & $\begin{array}{c}\text { Sig. } \\
\text { Tidak Sig.(F4) }\end{array}$ \\
\hline & F2 & & 0,585 & 0,782 & Sig. \\
\hline & $\mathrm{F3}$ & & 0,641 & 0,791 & Sig. \\
\hline & $\mathrm{F} 4$ & & 0,354 & 0,779 & $\begin{array}{c}\text { Sig. } \\
\text { Tidak Sig.(F1) }\end{array}$ \\
\hline & F5 & & 0,739 & 0,787 & Sig. \\
\hline
\end{tabular}

\begin{tabular}{|c|c|c|c|c|c|}
\hline Var. & Ind. & $\begin{array}{r}\begin{array}{r}\text { Nilai } \\
\text { KMO }\end{array} \\
\end{array}$ & $\begin{array}{l}\text { Sumb. } \\
\text { Efektif }\end{array}$ & $\begin{array}{c}\text { Koef. } \\
\text { Korelasi }\end{array}$ & Ket. \\
\hline \multirow{6}{*}{$\begin{array}{l}\text { 䓀 } \\
\text { 棁 }\end{array}$} & G1 & \multirow{6}{*}{0,738} & 0,742 & 0,752 & $\begin{array}{c}\text { Sig. } \\
\text { Tidak Sig. (G) }\end{array}$ \\
\hline & G2 & & 0,702 & 0,715 & $\begin{array}{l}\text { Sig. (G4) } \\
\text { Tidak Sig. }\end{array}$ \\
\hline & G3 & & 0,700 & 0,709 & $\begin{array}{l}\text { Sig. } \\
\text { Sig. }\end{array}$ \\
\hline & $\mathrm{G} 4$ & & 0,840 & 0,779 & $\begin{array}{l}\text { Sig. } \\
\text { Tidak Sig. (G2) }\end{array}$ \\
\hline & G5 & & 0,768 & 0,686 & $\begin{array}{l}\text { Sig. } \\
\text { Tidak Sig. } \\
\text { (G1\&G2) }\end{array}$ \\
\hline & $\mathrm{G} 6$ & & 0,845 & 0,773 & Sig. \\
\hline \multirow{3}{*}{ 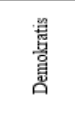 } & H1 & \multirow{3}{*}{0,627} & 0,546 & 0,700 & Sig. \\
\hline & $\mathrm{H} 2$ & & 0,771 & 0,587 & Sig. \\
\hline & $\mathrm{H} 3$ & & 0,647 & 0,631 & Sig. \\
\hline \multirow{3}{*}{ 嵒悬声 } & I1 & \multirow{3}{*}{0,699} & 0,666 & 0,762 & Sig. \\
\hline & I2 & & 0,775 & 0,661 & Sig. \\
\hline & 13 & & 0,730 & 0,693 & Sig. \\
\hline \multirow{3}{*}{ 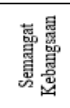 } & $\mathrm{J} 1$ & \multirow{3}{*}{0,606} & 0,787 & 0,570 & Sig. \\
\hline & $\mathrm{J} 2$ & & 0,588 & 0,636 & Sig. \\
\hline & $\mathrm{J} 3$ & & 0,584 & 0,638 & Sig. \\
\hline 悬皇 & $\begin{array}{l}\mathrm{K} 1 \\
\mathrm{~K} 2 \\
\mathrm{~K} 3 \\
\mathrm{~K} 4 \\
\mathrm{~K} 5 \\
\end{array}$ & 0,741 & $\begin{array}{c}0,605 \\
0,683 \\
0,843 \\
0,735 \\
0,583 \\
\end{array}$ & $\begin{array}{c}0,767 \\
0,727 \\
0,727 \\
0,767 \\
0,747 \\
0,691 \\
\end{array}$ & $\begin{array}{l}\text { Sig. } \\
\text { Sig. } \\
\text { Sig. } \\
\text { Sig. } \\
\text { Sig. }\end{array}$ \\
\hline \multirow{3}{*}{ 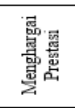 } & L1 & \multirow{3}{*}{0,666} & 0,740 & 0,713 & Sig. \\
\hline & L2 & & 0,882 & 0,610 & Sig. \\
\hline & L3 & & 0,748 & 0,705 & Sig. \\
\hline \multirow{3}{*}{ 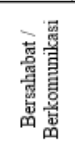 } & M1 & \multirow{3}{*}{0,698} & 0,848 & 0,654 & Sig. \\
\hline & M2 & & 0,853 & 0,650 & Sig. \\
\hline & M3 & & 0,689 & 0,865 & Sig. \\
\hline \multirow{2}{*}{ 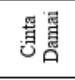 } & N1 & \multirow[b]{2}{*}{0,686} & 0,825 & 0,683 & Sig. \\
\hline & $\mathrm{N} 2$ & & 0,898 & 0,625 & Sig. \\
\hline \multirow{4}{*}{ 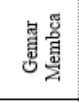 } & 01 & \multirow{4}{*}{0,788} & $\frac{0,740}{0,937}$ & $\begin{array}{l}0,795 \\
0,703\end{array}$ & $\begin{array}{l}\text { Sig. } \\
\text { Sig. }\end{array}$ \\
\hline & 02 & & 0,905 & 0,721 & Sig. \\
\hline & $\mathrm{O} 3$ & & 0,840 & 0,881 & Sig. \\
\hline & 04 & & 0,801 & 0,921 & Sig. \\
\hline \multirow{4}{*}{ 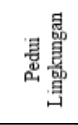 } & P1 & \multirow{4}{*}{0,765} & 0,595 & 0,861 & Sig. \\
\hline & $\mathrm{P2}$ & & 0,822 & 0,717 & Sig. \\
\hline & P3 & & 0,825 & 0,702 & Sig. \\
\hline & $\mathrm{P} 4$ & & 0,720 & 0,853 & Sig. \\
\hline \multirow{3}{*}{ 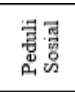 } & Q1 & \multirow{3}{*}{0,645} & 0,863 & 0,594 & Sig. \\
\hline & Q2 & & 0,807 & 0,617 & Sig. \\
\hline & Q3 & & 0,594 & 0,824 & Sig. \\
\hline \multirow{3}{*}{ 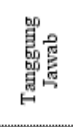 } & $R 1$ & \multirow{3}{*}{0,706} & 0,707 & 0,737 & Sig. \\
\hline & $\mathrm{R} 2$ & & 0,789 & 0,664 & Sig. \\
\hline & R3 & & 0,715 & 0,728 & Sig. \\
\hline
\end{tabular}

Berdasarkan tabel hasil analisis uji lapangan awal dapat disimpulkan: (1) pada nilai KMO menunjukkan bahwa penggunaan analisis faktor tepat untuk menganalisis tiap-tiap indikator pada keseluruhan nilai karakter, (2) seluruh indikator memberikan sumbangan yang efektif terhadap faktor dalam variabel tiap-tiap nilai karakter, (3) beberapa indikator pada tiap-tiap nilai karakter berkorelasi kuat dan signifikan dengan indikator yang lain. 
Pengembangan Model Penilaian.

Veny \& Widi

\section{Hasil uji lapangan utama}

Hasil uji lapangan utama pengembangan model penilaian pendidikan karakter anak usia dini di TK Tauladan dan TK Dharma Wanita Pelem Kecamatan Pare disajikan pada tabel 3.

Tabel 3. Hasil Analisis Uji Lapangan

\section{Utama}

\begin{tabular}{|c|c|c|c|c|c|}
\hline Var. & Ind. & $\begin{array}{r}\text { Nilai } \\
\text { KMO } \\
\end{array}$ & $\begin{array}{l}\text { Sumb. } \\
\text { Efektif }\end{array}$ & $\begin{array}{c}\text { Koef. } \\
\text { Korelasi }\end{array}$ & Ket. \\
\hline \multirow{4}{*}{ 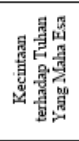 } & $\mathrm{Al}$ & \multirow{4}{*}{0,734} & 0,732 & 0,682 & Sig. \\
\hline & $\mathrm{A}_{2}$ & & 0,660 & 0,726 & Sig. \\
\hline & $\mathrm{A}_{3}$ & & 0,645 & 0,767 & Sig. \\
\hline & $\mathrm{A} 4$ & & 0,395 & 0,831 & Sig. \\
\hline \multirow{3}{*}{ 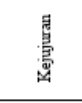 } & B1 & \multirow{3}{*}{0,753} & 0,853 & 0,730 & Sig. \\
\hline & B2 & & 0,830 & 0,766 & Sig. \\
\hline & B3 & & 0,830 & 0,766 & Sig. \\
\hline \multirow{3}{*}{ 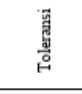 } & $\mathrm{Cl}$ & \multirow{3}{*}{0,678} & 0,732 & 0,675 & Sig. \\
\hline & $\mathrm{C} 2$ & & 0,809 & 0,629 & Sig. \\
\hline & C3 & & 0,644 & 0,765 & Sig. \\
\hline \multirow{3}{*}{ 昜 } & Dl & \multirow{3}{*}{0,527} & 0,169 & 0,719 & Tidak Sig. \\
\hline & D2 & & 0,747 & 0,518 & Sig. \\
\hline & D3 & & 0,782 & 0,517 & Sig. \\
\hline \multirow{4}{*}{ 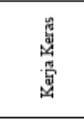 } & El & \multirow{4}{*}{0,823} & 0,643 & 0,808 & Sig. \\
\hline & E2 & & 0,776 & 0,769 & Sig. \\
\hline & $\mathrm{E} 3$ & & 0,695 & 0,823 & Sig. \\
\hline & E4 & & 0,705 & 0,803 & Sig. \\
\hline \multirow{5}{*}{ 䨗 } & $\mathrm{Fl}$ & \multirow{5}{*}{0,859} & 0,629 & 0,868 & Sig. \\
\hline & $\mathrm{F} 2$ & & 0,812 & 0,800 & Sig. \\
\hline & F3 & & 0,737 & 0,857 & Sig. \\
\hline & $\mathrm{F} 4$ & & 0,579 & 0,902 & Sig. \\
\hline & F5 & & 0,572 & 0,911 & Sig. \\
\hline \multirow{3}{*}{ 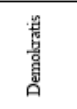 } & $\mathrm{Hl}$ & \multirow{3}{*}{0,605} & 0,420 & 0,800 & Sig. \\
\hline & $\mathrm{Hz}$ & & 0,764 & 0,572 & Sig. \\
\hline & $\mathrm{H} 3$ & & 0,734 & 0,579 & Sig. \\
\hline \multirow{3}{*}{ 票望見 } & Il & \multirow{3}{*}{0,654} & 0,561 & 0,850 & Sig. \\
\hline & I2 & & 0,811 & 0,612 & Sig. \\
\hline & $\mathrm{I3}$ & & 0,802 & 0,615 & Sig. \\
\hline \multirow{3}{*}{ 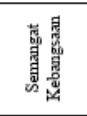 } & $\mathrm{Jl}$ & \multirow{3}{*}{0,691} & 0,681 & 0,702 & Sig. \\
\hline & $\mathrm{J} 2$ & & 0,745 & 0,656 & Sig. \\
\hline & J3 & & 0,655 & 0,727 & Sig. \\
\hline \multirow{5}{*}{ 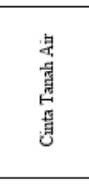 } & $\mathrm{Kl}$ & \multirow{5}{*}{0,731} & 0,543 & 0,835 & Sig. \\
\hline & $\mathrm{K} 2$ & & 0,381 & 0,720 & $\begin{array}{c}\text { Sig. } \\
\text { Tidak Sig (K5) }\end{array}$ \\
\hline & K3 & & 0,859 & 0,670 & Sig. \\
\hline & $\mathrm{K} 4$ & & 0,641 & 0,749 & sig. \\
\hline & K5 & & 0,528 & 0,743 & $\begin{array}{c}\text { Sig. } \\
\text { Tidak Siz. }(\mathrm{K} 2)\end{array}$ \\
\hline \multirow{3}{*}{ 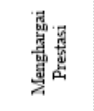 } & L1 & \multirow{3}{*}{0,644} & 0,740 & 0,641 & Sig. \\
\hline & $\mathrm{L} 2$ & & 0,843 & 0,596 & Sig. \\
\hline & $\mathrm{L} 3$ & & 0,617 & 0,746 & Sig. \\
\hline
\end{tabular}

Berdasarkan tabel hasil analisis uji lapangan awal dapat disimpulkan:(1) pada nilai KMO menunjukkan bahwa penggunaan analisis faktor tepat untuk

\begin{tabular}{|c|c|c|c|c|c|}
\hline \multirow{3}{*}{ 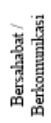 } & Ml & \multirow{3}{*}{0,683} & 0,730 & 0,656 & Sig. \\
\hline & $\mathrm{M} 2$ & & 0,728 & 0,657 & Sig. \\
\hline & M3 & & 0,608 & 0,766 & Sig. \\
\hline \multirow{3}{*}{ 䡒 } & N1 & \multirow{3}{*}{0,682} & 0,722 & 0,712 & Sig. \\
\hline & $\mathrm{N} 2$ & & 0,837 & 0,629 & Sig. \\
\hline & $\mathrm{N} 3$ & & 0,705 & 0,730 & $\mathrm{Sig}$ \\
\hline \multirow{4}{*}{ 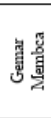 } & Ol & \multirow{4}{*}{0,816} & 0,821 & 0,787 & Sig. \\
\hline & 02 & & 0,632 & 0,869 & Sig. \\
\hline & 03 & & 0,861 & 0,788 & Sig. \\
\hline & 04 & & 0,804 & 0,845 & Sig. \\
\hline \multirow{4}{*}{ 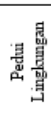 } & P1 & \multirow{4}{*}{0,688} & 0,456 & 0,719 & Sig. \\
\hline & $\mathrm{P} 2$ & & 0,790 & 0,666 & Sig. \\
\hline & P3 & & 0,785 & 0,665 & Sig. \\
\hline & P4 & & 0,516 & 0,745 & Sig. \\
\hline \multirow{3}{*}{ 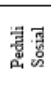 } & Q1 & \multirow{3}{*}{0,715} & 0,726 & 0,767 & Sig. \\
\hline & Q2 & & 0,817 & 0,670 & Sig. \\
\hline & Q3 & & 0,761 & 0,723 & Sig. \\
\hline \multirow{3}{*}{ 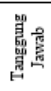 } & $\mathrm{Rl}$ & \multirow{3}{*}{0,641} & 0,583 & 0,762 & Sig. \\
\hline & $\mathrm{R} 2$ & & 0,740 & 0,629 & Sig. \\
\hline & $\mathrm{R} 3$ & & 0,829 & 0,595 & Sig. \\
\hline
\end{tabular}

menganalisis tiap-tiap indikator pada keseluruhan nilai karakter, (2) seluruh indikator memberikan sumbangan yang efektif terhadap faktor dalam variabel tiap-tiap nilai karakter, (3) hampir semua indikator pada tiap-tiap nilai karakter berkorelasi kuat dan signifikan dengan indikator yang lain. Hasil analisis data keefektifan penggunaan model berdasarkan tabel dapat disimpulkan bahwa total nilai dari sepuluh item sebesar 498 yang artinya model sangat efektif (lihat gambar 1)

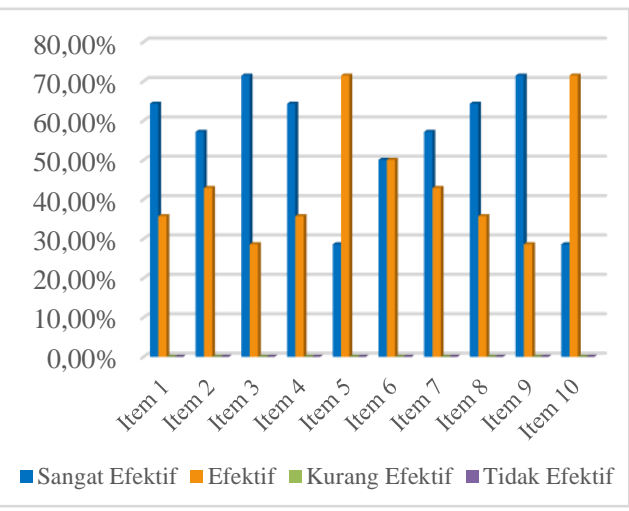

Gambar 1. Analisis Per Item 


\section{KESIMPULAN}

Hasil analisis faktor pada 65 indikator menghasilkan korelasi yang kuat dan signifikan, sehingga model penilaian yang telah dikembangkan layak digunakan dan dapat menilai pendidikan karakter yang telah diajarkan. Hasil analisis angket keefektifan penggunaan model penilaian pendidikan karakter anak usia dini diperoleh skor sebesar 498, hal ini berarti penggunaan model penilaian pendidikan karakter sangat efektif untuk digunakan di sekolah Taman Kanak-kanak.

\section{DAFTAR PUSTAKA}

Arndt, S., \& Tesar, M. (2015). Early childhood assessment in Aotearoa New Zealand: Critical perspectives and fresh openings, 6(2), 71-86. https://doi.org/10.1515/jped-20150014

Chasanah, R. (2014). Pendidikan Karakter MelaluiPercobaan Sains Sederhana untuk Anak Usia Dini. Yogyakarta: Kreasi Wacana.

Dimerman, S. (2009). Character is The Key. Canada: Wiley.

Dirjen PAUD, D. J. P. A. U. D. K. P. N. Pendidikan karakter pada pendidikan anak usia dini (2012).

Emzir. (2012). Metodologi Penelitian Pendidikan Kuantitatif dan Kualitatif. Jakarta: PT. RajaGrafindo Persada.

Gunawan, H. (2012). Pendidikan Karakter. Bandung: Alfabeta.

Khoiriyah. (2016). Pendidikan Karakter Pada Anak Usia Dini Melalui Bermain. Jurnal PAUD Kajian Teori Dan Praktik Pendidikan Anak Usia Dini, 2(1), 39-45.

Komalasari, K., \& Saripudin, D. (2017). Pendidikan Karakter: Konsep dan Aplikasi Living Values Education. Bandung: Refika Aditama.
Kusaeri, \& Suprananto. (2012). Pengukuran dan Penilaian Pendidikan. Yogyakarta: Graha Ilmu.

Lestariningrum, A. (2016). Perencanaan Pembelajaran Anak Usia Dini. Kediri: Adjie MediaNusantara.

Lickona, T. (2013). Pendidikan Karakter Panduan Lengkap Mendidik Siswa Menjadi Pintar dan Baik. Terjemahan Lita S. Bandung: Nusa Media.

Mardapi, D. (2012). Pengukuran, Penilaian, dan Evaluasi Pendidikan. Yogyakarta: Nuha Litera.

Park, N., \& Peterson, C. . (2004). Assessment Of Character Strengths Among Youth: The Values In Action Inventory Of Strengths For Youth. Positif DevelopmentConference in the USA. Sage Journals.

Retnawati, H. (2016). Validitas, Reliabilitas, dan Karakteristik Butir. Yogyakarta: Parama Publishing.

Rohita, \& Nurfadilah. (2017). Pelaksanaan Penilaian Pembelajaran di Taman Kanak- Kanak (Studi Deskriptif pada Taman Kanak-kanak di Jakarta) 1, (1), 53-62.

Runtukahu, J. T., \& Kandou, S. (2014). Pembelajaran Matematika Dasar Bagi Anak Berkesulitan Belajar. Yogyakarta: Ar-ruzz Media.

Sutijan, Makhfud, H., Lestari, L., \& Chumdari. (2015). pengembangan instrumen penilaian pendidikan karakter terpadu, 18(2).

Suyanto, S. (2012). Pendidikan Karakter untuk Anak Usia Dini. Jurnal Pendidikan Anak, 1(1), 1-10.

Yusuf, A. . (2009). Penerapan Assessment (Penilaian) Pendidikan Anak Usia Dini Ala Indonesia. Pertemuan Ilmiah Forum FIP-JIP Se-Indonesia, $1-18$.

Zulkifli, I. N., Majid, R. A., \& Hassan, A. (2016). The Assessment of Children 's Performance at Child Care Centre. Procedia - Social and Behavioral Sciences, 234, 64-73. https://doi.org/10.1016/j.sbspro.2016 .10 .220 